\title{
Batch elimination of cationic dye from aqueous solution by electrocoagulation process
}

\author{
Fatima Ezzahra Titchou, Hanane Afanga, Hicham Zazou, Rachid Ait Akbour and Mohamed Hamdani * \\ Ibn Zohr University, Faculty of Sciences, Chemical department, BO 8106-Dakhla district, Agadir, Morocco
}

\begin{abstract}
Like other developing countries, Morocco has undergone a real industrial revolution that generates a huge amount of colored wastewater. Methylene blue (MB) could be considered as commonly model of cationic dyes that are widely used in industries. In the present work, the removal of MB was investigated in the presence of $\mathrm{NaCl}$ as electrolyte by electrocoagulation (EC) process. Parameters studied are the nature of electrodes, electrode spacing, initial dye concentration, agitation speed, applied current density, $\mathrm{NaCl}$ concentration, and the effect of the initial pH. Stainless steel electrodes have been used as cathode and anode in the electrochemical cell. The performance of the process was evaluated in terms of color removal, chemical oxygen demand (COD), total organic carbon (TOC), electrical power consumption, current efficiency, and the quantity of sludge formed. The results showed that the removal percent of $20 \mathrm{mg} / \mathrm{L} \mathrm{MB}$ is $100 \%$, using stainless steel electrodes with an interspace of $1.5 \mathrm{~cm}$ and $20 \mathrm{~mA} / \mathrm{cm}^{2}$ for $6 \mathrm{~min}$ in the presence of $0.1 \mathrm{M} \mathrm{NaCl}$ at natural $\mathrm{pH}$. COD and TOC removals within $15 \mathrm{~min}$ were $45 \%$ and $51 \%$ respectively. The power consumption, in that case, was $5.84 \mathrm{KWh} / \mathrm{m}^{3}$, while the amount of sludge formed was $1.64 \mathrm{Kg} / \mathrm{m}^{3}$.
\end{abstract}

Keywords: Electrocoagulation, Dyes, Methylene blue, Sludge, Stainless Steel electrodes.

\section{Introduction}

The dyeing and finishing processes in the textile industries produce a considerable quantity of dyestuff ${ }^{1}$. Generally, this wastewater has low biodegradability and is known for its higher value of $\mathrm{pH}$, temperature and COD. The effluents of textile industries have allergic, toxic, mutagenic or cancerogenic properties which create a severe problem in front of the environment protection ${ }^{2,3}$. Industries produce about $7 \times 10^{8} \mathrm{Kg} /$ year of dyes and about 5 to $10 \%$ among them are unacceptable as industrial wastes ${ }^{4}$. To remove dyes from wastewaters, a variety of treatments, such as electro-Fenton processes 5, coagulation-flocculation 6 biological degradation, adsorption, photodegradation, ozonation 7-9, membrane separation ${ }^{10}$ have been reported. Some of those methods produce a large amount of sludge, and their efficiency is not sufficient.

On the other hand, some of them are limited by their high operation costs ${ }^{11}$. During the last few decades, the electrocoagulation (EC) process is observed to be a prominent technique for wastewater treatment. This technology has many advantages in being attractive for its versatility, ease of control, safety, selectivity, and being able for automation ${ }^{12}$. It involves the insitu generation of the coagulants by the application of direct current voltage to oxidize a sacrificial anode such as $\mathrm{Fe}^{13}, \mathrm{Al}^{14}$, and stainless steel ${ }^{15}$ to form flocs.

*Corresponding author: Mohamed Hamdani

Email address: hamdani.mohamed@gmail.com

DOI: http://dx.doi.org/10.13171/mjc10102001201163mh
Moreover, eliminate organic compounds from wastewater ${ }^{3}$. The process occurs under three successive stages; (i) electrolytic oxidation of sacrificial anode and production of coagulant, (ii) formation of flocs after the destabilization of organic compounds and particulate suspension, (iii) formation of sludge by the aggregation of destabilized particulate.

This process happens as follows:

$$
\begin{aligned}
& \text { At the anode: } \quad \begin{array}{l}
\mathrm{M} \rightarrow \mathrm{M}^{\mathrm{n}+}+\mathrm{ne}^{-} \\
2 \mathrm{H}_{2} \mathrm{O} \rightarrow 4 \mathrm{H}^{+}+\mathrm{O}_{2}+4 \mathrm{e}^{-}
\end{array} \\
& \begin{array}{l}
\text { At the cathode: } \\
\mathrm{nH} \mathrm{H}_{2} \mathrm{O}+\mathrm{ne}^{-} \rightarrow \frac{n}{2} \mathrm{H}_{2}+\mathrm{nOH}^{-} \\
\qquad \mathrm{M}^{\mathrm{n}+}+\mathrm{ne}^{-} \rightarrow \mathrm{M}
\end{array} \\
& \text { In the bulk of solution: } \mathrm{M}^{\mathrm{n}+}+\mathrm{nOH}^{-} \rightarrow \mathrm{M}(\mathrm{OH})_{\mathrm{n}}
\end{aligned}
$$

Where ' $M$ ' is the anode material and ' $n$ ' is the number of electrons involved in the reaction ${ }^{16,17}$. There are four mechanisms of destabilization that could occur after the formation of the insoluble polymeric metal hydroxides. It may realize the surface complexation; when the dye acts as a ligand to link the polymers formed. The electrostatic attraction; where dyes neutralize the surface charge on the $\mathrm{M}(\mathrm{OH})_{\mathrm{n}}$, compress the diffuse double layer due to the increase of the metal ion concentration in the bulk of the solution, and finally by the chain 
oxidation reaction in the presence of $\mathrm{NaCl}$ that may enhance the formation of the mono and the polynuclear hydroxide form of the metal ${ }^{4,18}$.

The anodically produced chlorine species enhance the indirect electrolysis that transforms pollutants into less harmful products. The main forms are active chlorine in form gaseous, hypochloruous acid, hypochlorite and $\mathrm{Cl}^{-}$ions.

$$
\begin{aligned}
& 2 \mathrm{Cl}^{-} \rightarrow \mathrm{Cl}_{2}+2 \mathrm{e}^{-} \\
& \mathrm{Cl}_{2}+\mathrm{H}_{2} \mathrm{O} \rightarrow \mathrm{HOCl}+\mathrm{H}^{+}+\mathrm{Cl}^{-} \\
& \mathrm{HOCl} \rightarrow \mathrm{H}^{+}+\mathrm{OCl}^{-}
\end{aligned}
$$

The overall reaction can be written as:

Dye $+\mathrm{OCl}^{-} \rightarrow$ Intermediates $\rightarrow \mathrm{CO}_{2(\mathrm{~g})}+\mathrm{H}_{2} \mathrm{O}+\mathrm{Cl}^{-}$

A number of researchers used the EC process to treat different kind of dyes as Disperse Yellow $54{ }^{16}$, Indigo Carmine ${ }^{13}$, Reactive Black $5^{19}$, Reactive Red $198^{20}$, and Methylene Blue ${ }^{21,14}$. Performances of treatment were also tested on real wastewater as reported by others ${ }^{22-26}$. Electrocoagulation method was adopted to treat pharmaceuticals effluents ${ }^{27,28}$, heavy metals like chromium ${ }^{29}$,copper and nickel ${ }^{30}$, and nonmetallic inorganic species as phosphate ${ }^{31}$ and sulfate 32.

Methylene blue (MB) is a cationic dye, widely used for different dyeing processes for wool, cotton, silk, etc. In the event of exposure, it may lead to eye damage, mental confusion, nausea, vomiting and methamoglobinemia ${ }^{33}$. Many researchers have studied textile dyes treatment using EC process; however, very few studies on methylene blue dye removal using stainless steel electrodes is accessible till date. This paper aims to study the elimination of MB from water using stainless steel electrodes. The optimization of some parameters, such as current density, the initial $\mathrm{pH}$, initial dye concentration, supporting electrolyte concentration, COD, TOC, color removal, power consumption, and the amount of the sludge formed, has been carried out during the electrocoagulation process and results, so obtained, are presented in this paper.

\section{Materials and methods}

The MB dye $\left(\mathrm{C}_{16} \mathrm{H}_{18} \mathrm{ClN}_{3} \mathrm{~S} . \mathrm{H}_{2} \mathrm{O}, \quad \mathrm{MW}=319.859\right.$ $\mathrm{g} / \mathrm{mol}$, purity $=82 \%$ ) purchased from Himedia company, was used in the present investigation without further purification. A solution of the dye having a concentration of $20 \mathrm{mg} / \mathrm{L}$ (stock solution) was prepared in distilled water. Less concentrated solutions ie $(5,10$, and $15 \mathrm{mg} / \mathrm{L})$ were prepared by dilution of the stock solution. Then $\mathrm{NaCl}$ concentrations $(0.05,0.09,0.10$, and $0.11 \mathrm{M})$ are adjusted by the addition of the required amount of salt to $\mathrm{MB}$ solutions. Natural $\mathrm{pH}$ of solutions is 5.86 whatever the concentrations of $\mathrm{MB}$ and salt. $\mathrm{A}$ solution of $20 \mathrm{mg} / \mathrm{L} \mathrm{MB}$ and $0.1 \mathrm{M} \mathrm{NaCl}$, present a conductivity around $14 \mathrm{mS} / \mathrm{cm}$.
The color removal was monitored by recording the absorption spectra of the electro-coagulated solution at $663 \mathrm{~nm}$ using UV-visible spectrophotometer (Hach, DR 6000). The percentage of color removal was calculated by using (Eq.1) ${ }^{34}$.

Color removal $(\%)=\frac{\mathrm{Abs}_{\mathrm{O}}-\mathrm{Abs}_{\mathrm{i}}}{\mathrm{Abs}_{\mathrm{O}}} \times 100$

The elimination of methylene blue was carried out with $400 \mathrm{ml}$ of the dye solution in a $600 \mathrm{ml}$ Pyrex bulker. During the experiment, a magnetic stirrer was used to secure the homogeneity of the solution. The observed initial $\mathrm{pH}$ of the solution was 5.86 as measured with HANNA pH-meter. The $\mathrm{pH}$ effect on the color removal was investigated using $0.5 \mathrm{M} \mathrm{H}_{2} \mathrm{SO}_{4}$ or $0.5 \mathrm{M} \mathrm{NaOH}$ (from Prolabo) to adjust the initial $\mathrm{pH}$ of the solution ${ }^{35}$, and its value was not further controlled. A stabilized alimentation (digital DC ELC, model ALR3002M) was used for the electrolysis at $25 \pm 2{ }^{\circ} \mathrm{C}$; the experimental set-up is presented in (Fig.1). The Chemical Oxygen Demand (COD) measurements were performed using Hach Lange cuvette test LCK314with a range of 0-150 mg O $2 / \mathrm{L}$ and its value was determined using Hach DR6000 spectrophotometer. Total Organic Carbon (TOC) measurements were determined by injecting $50 \mu \mathrm{L}$ sample through thermal catalytic oxidation at $680^{\circ} \mathrm{C}$ using TOC-L SHIMADZU analyzer. Before each analysis, samples were centrifuged at $4000 \mathrm{rpm}$ using Rotafix 32 A(Hetttich Zentrifugen). COD removal, TOC removal, and the power consumption were calculated according to equations given below ${ }^{34,36-38}$ :

$\begin{array}{ll}\text { COD removal }(\%)=\frac{\mathrm{COD}_{\mathrm{o}}-\mathrm{COD}}{\mathrm{COD}_{\mathrm{o}}} \times 100 & (\text { Eq. } 2) \\ \text { TOC removal }(\%)=\frac{\mathrm{TOC}_{\mathrm{o}}-\mathrm{TOC}}{\mathrm{TOC}} \times 100 & (\text { Eq.3) } \\ \text { Power consumption }\left(\mathrm{KWh} / \mathrm{m}^{3}\right)=\frac{\mathrm{E}_{\mathrm{cell}} \times \mathrm{I} \times \mathrm{t}}{1000 \times \mathrm{V}_{\mathrm{S}}} & (\text { Eq.4) }\end{array}$

where, $\mathrm{COD}_{\mathrm{o}}$ and $\mathrm{TOC}_{\mathrm{o}}$ correspond to initial COD and TOC, respectively, $\mathrm{E}_{\text {cell }}$ is the average of applied voltage on the cell $(\mathrm{V})$, ' $\mathrm{I}$ 'is the applied current intensity (A), ' $t$ ' represents the electrolysis time (h), and $\mathrm{V}_{\mathrm{s}}$ is the solution volume $(\mathrm{L})$.

The chemical composition of the formed sludge was determined using scanning electron microscopy (SEM) coupled with energy-dispersive X-ray spectroscopy (EDS) (SEM-EDAX TEAM apparatus). SEM micrographs were obtained with VEGA 3 TESCAN microscope at $10 \mathrm{KV}$.

To study the effect of the nature of electrodes, stainless steel (AISI 316) and Iron (99.5\% purity) plates having dimensions $6.6 \mathrm{~cm} \times 13.5 \mathrm{~cm} \times 0.2 \mathrm{~cm}$ with $64 \mathrm{~cm}^{2}$ submerged surface area were used to perform the experiments. Before each experiment, electrodes were polished on a fine emery paper (P1200), treated ultrasonically in a dilute $\mathrm{NaOH}$ solution for 30min to remove adsorbed substances on the electrode surface and then washed with distilled water. 


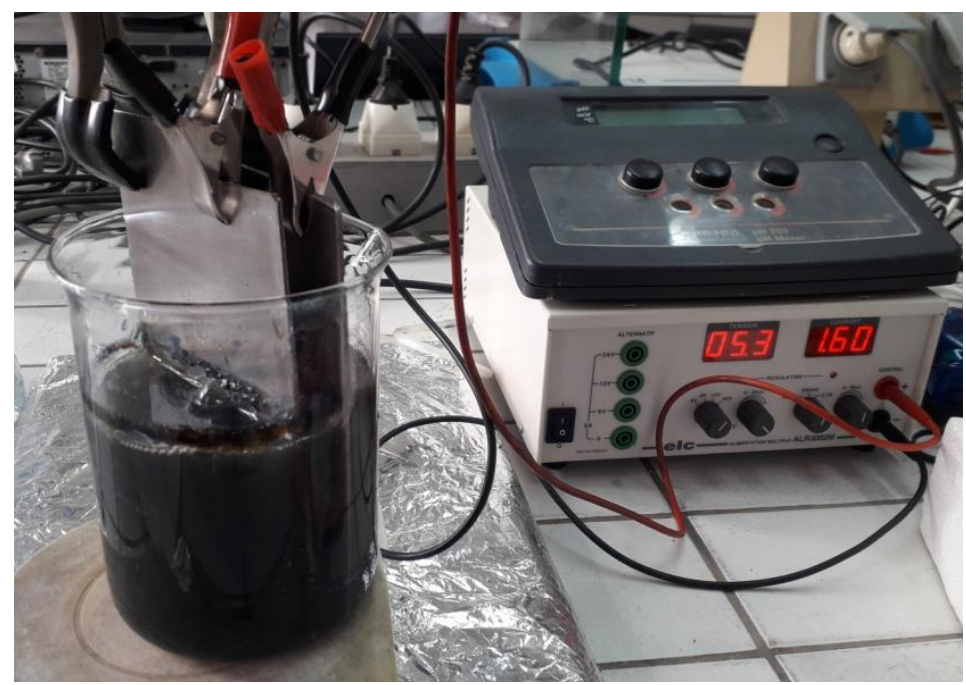

Figure 1. Experimental set-up of EC system

\section{Results and discussion}

3.1. Effect of electrodes' material on dye removal The effect of electrode materials on the removal of $\mathrm{MB}$ has been investigated using two different kinds of electrodes, i.e. stainless steel (SS) and Iron. The experiment was carried out at $20 \mathrm{~mA} / \mathrm{cm}^{2}$ using $0.1 \mathrm{M}$ $\mathrm{NaCl}$ at the solution with initial $\mathrm{pH}=5.86$. The color removal percentage vs time curve for the used electrodes is shown in (Fig. 2). From the figure, it is observed that MB elimination at stainless steel electrodes was found to be better as compared to Iron electrodes. The higher efficiency of SS may be because stainless steel promotes a higher potential of direct oxidation of the dye due to its high overpotential of oxygen evolution reaction compared to Iron ${ }^{15}$. Hence, further experiments have been performed by keeping SS as electrodes.

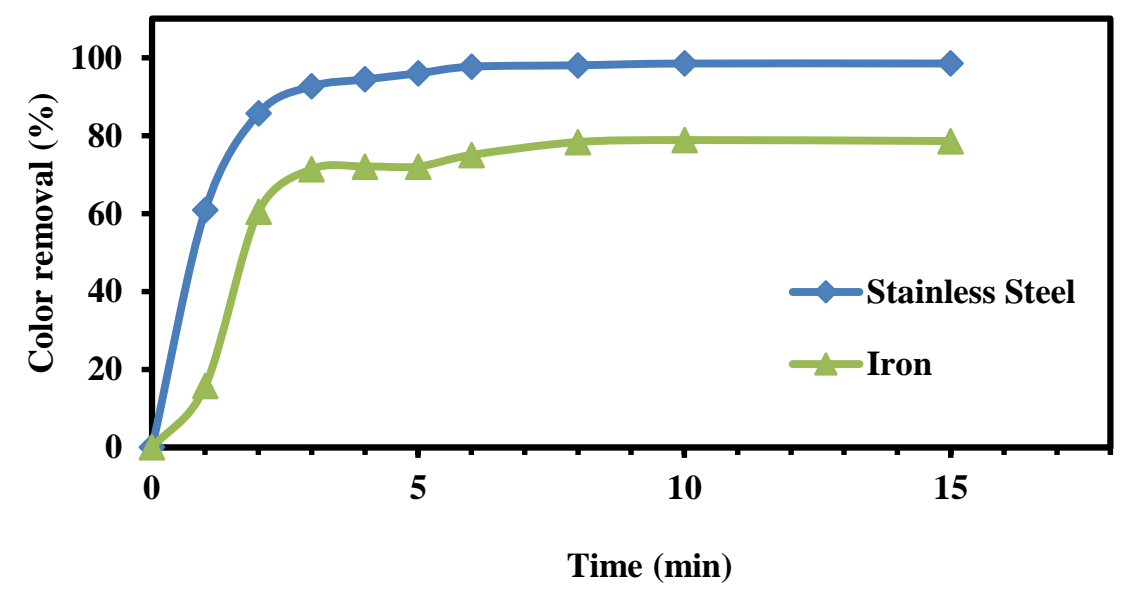

Figure 2. Color removal (\%) vs. time for stainless steel electrodes and Iron electrodes

\subsection{Effect of electrode spacing}

The potential drop $\left(\mathrm{V}_{\mathrm{iR}}\right)$, developed between electrodes is a valuable property that affects the electrode kinetic parameters of the electrochemical system. The power consumption and solution resistance decrease as the inter-electrode gap is reduced ${ }^{39}$. The effect of inter-electrode spacing has been investigated for $20 \mathrm{mg} / \mathrm{L}$ of $\mathrm{MB}$ at a current density of $15 \mathrm{~mA} / \mathrm{cm}^{2}$ in $0.1 \mathrm{M}$ of $\mathrm{NaCl}$ at natural $\mathrm{pH}$. The observed data for MB removal is represented in (Fig.3a). The results show that as the distance between electrodes increases from 1.0 to $2.0 \mathrm{~cm}$, the time for the total decolorization increases, accordingly. (Fig.3b) presents the power consumption computed at 6 min time electrolysis. The power consumption increases with increasing the inter-electrode distance due to the increase of electrical resistance of the solution between electrodes. Thus, the current passed through the electrodes decreases leading to low production of oxidizing species and polymeric metal hydroxides which give less decolorization efficiency 40 . Therefore, as the power consumption obtained using $1.5 \mathrm{~cm}$ inter-electrode space does not significantly increase, it is reasonable, in the current study, to adopt the later parameter for all further studies to avoid the accumulation of gas bubbles between electrodes in case of tiny gaps ${ }^{41}$. Aoudj et al. $^{42}$ reported that removal of Red 81 dye was achieved using a pair of aluminum electrodes with spacing $1.5 \mathrm{~cm}$. 

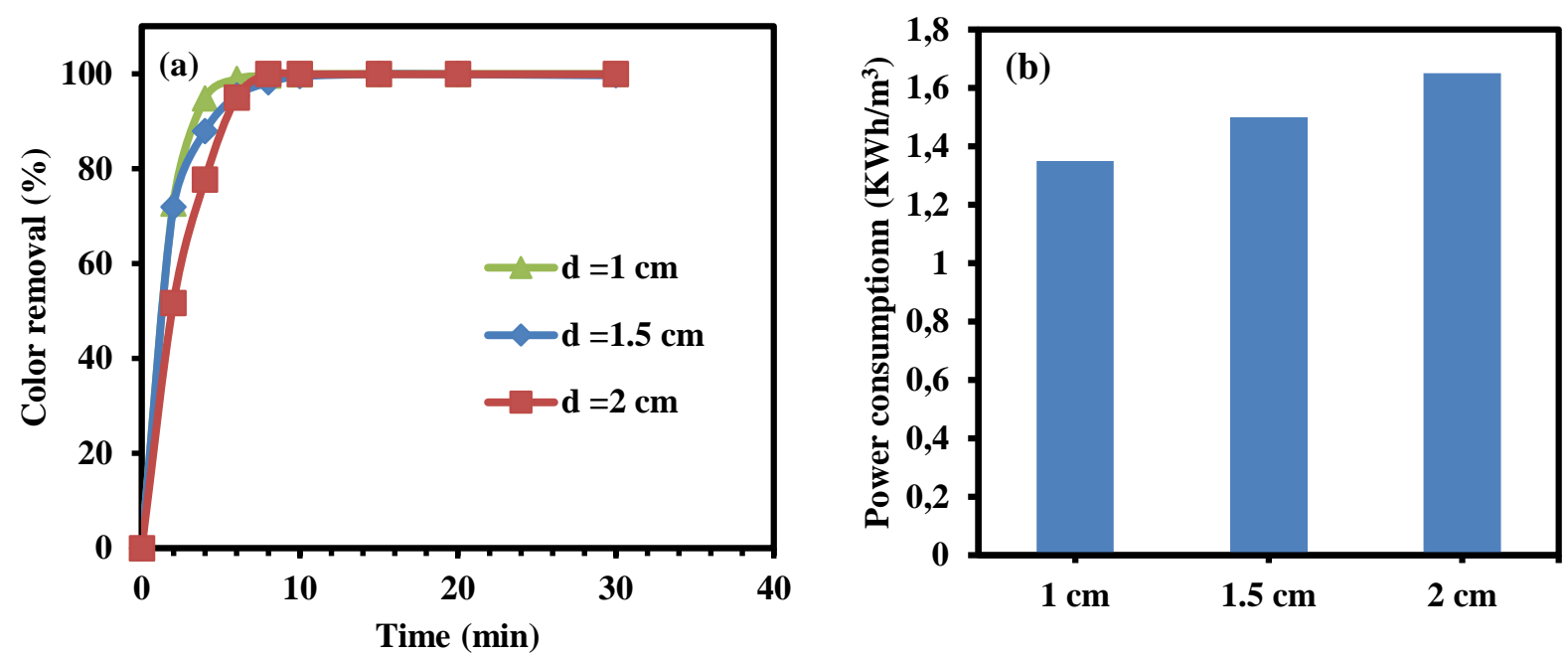

Figure 3. Effect of the inter-electrode distance for SS electrodes on: (a): Color removal (\%); (b): Power consumption

\subsection{Effect of the initial dye concentration}

The effect of the initial concentration of $\mathrm{MB}$ was studied at a current density of $20 \mathrm{~mA} / \mathrm{cm}^{2}$ using $0.1 \mathrm{M}$ of $\mathrm{NaCl}$ at $\mathrm{pH}=5.86$ (Fig.4). The removal efficiency decreases with increasing dye concentration. At higher concentration, the intermediate compounds compete with dye molecules and water on active sites of the electrode as reported by Modirshahla et al. ${ }^{43}$. Adsorption on iron hydroxide is the main dye removal pathway ${ }^{44}$. According to Faraday's law, a constant amount of coagulation ions is liberated from the sacrificial anode for the same current density and electrolyzing time. Consequently, the same quantity of coagulants will be produced in the solution. Therefore, the formed flocs, at high pollutant concentrations, will not be sufficient to absorb all pollutant $^{45}$.

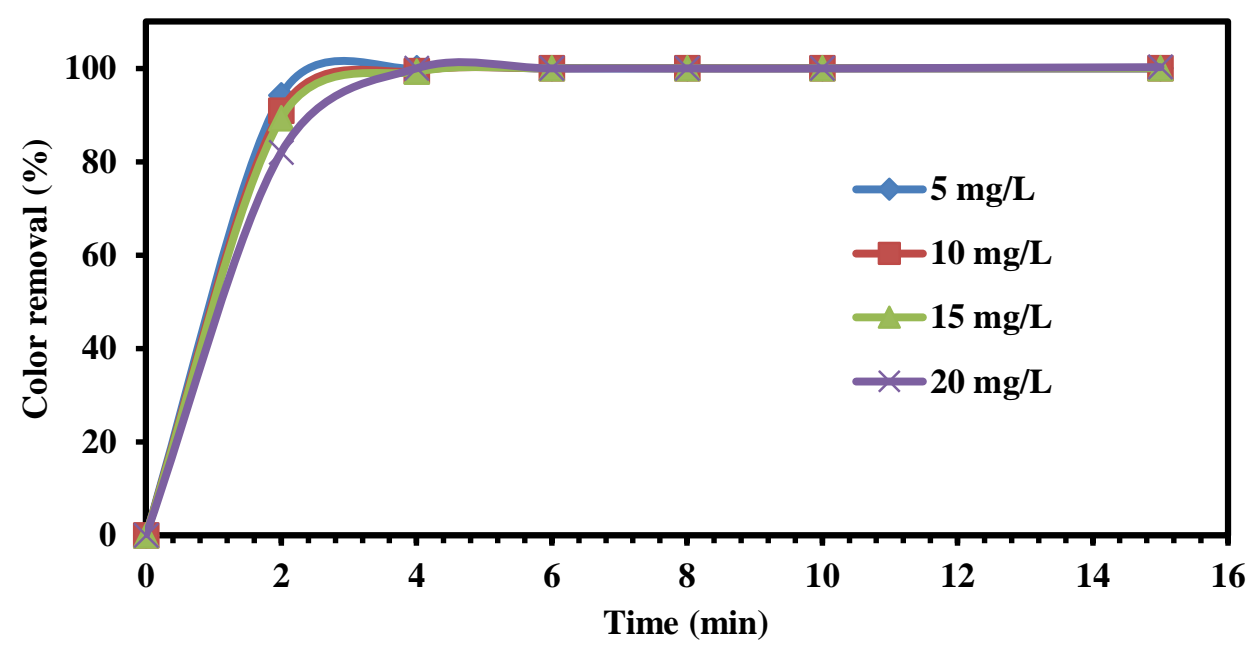

Figure 4. Effect of the initial dye concentration

\subsection{Effect of agitation speed}

The stirring magnetic effect was carried out using 20 $\mathrm{mg} / \mathrm{L} \mathrm{MB}, 0.1 \mathrm{M} \mathrm{NaCl}$ at natural $\mathrm{pH}$, and a current density of $15 \mathrm{~mA} / \mathrm{cm}^{2}$. The removal efficiency increases with increasing agitation speed (Fig. 5). The agitation enhances mixing between gel and dye molecules and thus flocs formation, leading to easier precipitation and an increasing pollution removal efficiency ${ }^{46}$. The increase in color removal may be ascribed to the following: (i) stirring improves the mixing conditions between the coagulants $\left[\mathrm{Fe}(\mathrm{OH})_{3}\right]$ and the dye molecules avoiding the formation of a gradient of concentration inside the reactor (ii) stirring eliminates concentration polarization at the anode with a consequent decrease in its passivation tendency 47. Raising the stirring rate leads to intensifying the mobility of the electrogenerated ions, which have a positive effect on color removal. 


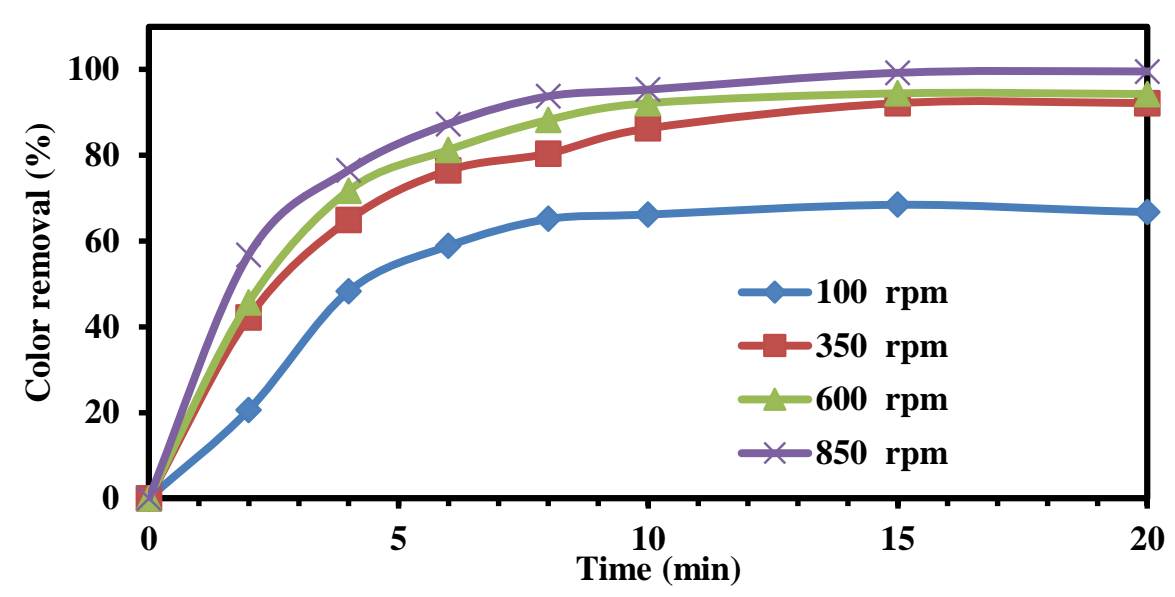

Figure 5. Effect of the agitation speed

\subsection{Effect of current density on removal efficiency} The current density, which can be controlled directly, is an essential parameter for the electrocoagulation process. It determines the quantity of the coagulant dissolved in the solution, the size of the flocs formed and hydrogen bubble production rates. Higher current density leads to generate more coagulant agents ${ }^{48,49}$; more $\mathrm{H}_{2}$ bubble is generated, thereby increasing the formation of metal hydroxide and treatment efficiency ${ }^{40,50}$. (Fig.6) represents the effect of current density for $\mathrm{MB}$ removal using $0.1 \mathrm{M} \mathrm{NaCl}$ with $1.5 \mathrm{~cm}$ interelectrode spacing for different electrolysis times. The results show that the efficiency of color removal is increased with increasing current density upto20 $\mathrm{mA} / \mathrm{cm}^{2}$, and then it remains constant. The treatment time required for $\mathrm{MB}$ removal decreases with increasing the current density. For instance, after 20 minutes of treatment, a current density of $10 \mathrm{~mA} / \mathrm{cm}^{2}$ is required to achieve about $99 \%$ removal of dye, while after 6 minutes of treatment $100 \%$ dye removal is obtained at the current density of $20 \mathrm{~mA} / \mathrm{cm}^{2}$. Therefore, for the study of the next parameters, 20 $\mathrm{mA} / \mathrm{cm}^{2}$ is taken as the optimum current density.

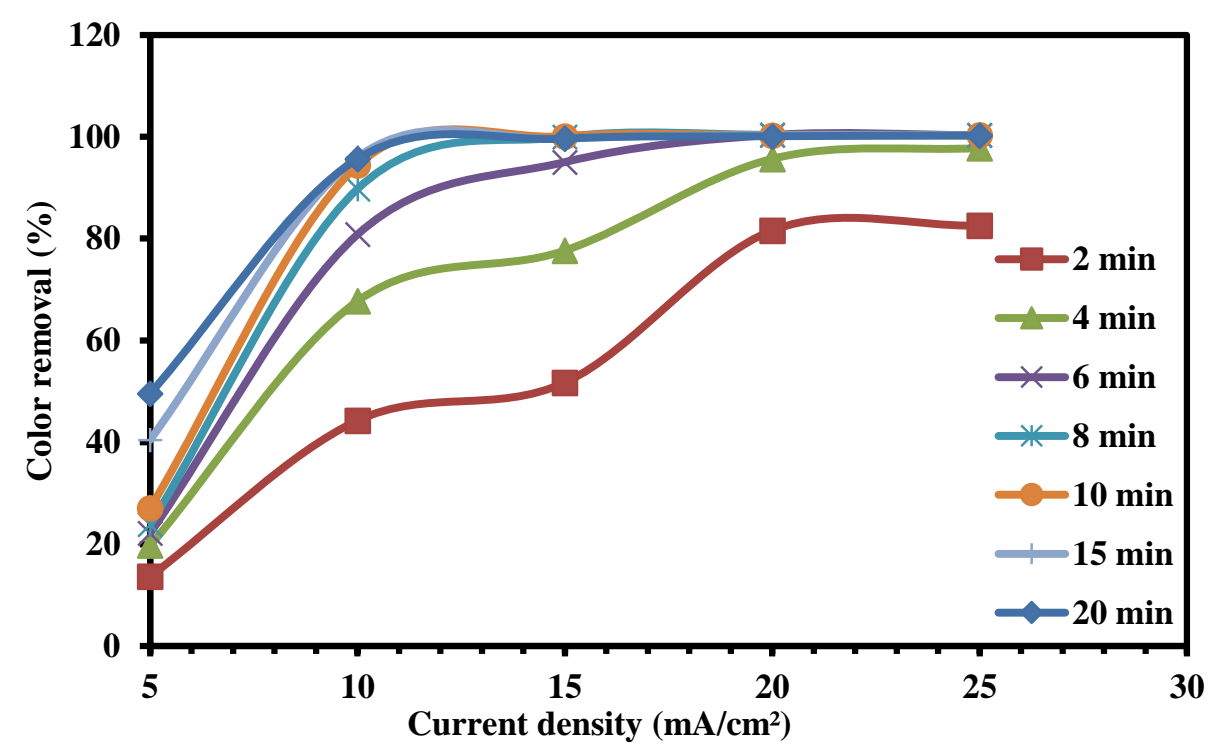

Figure 6. Effect of current density for the elimination of MB $(20 \mathrm{mg} / \mathrm{L})$

\subsection{Effect of the concentration of the supporting} electrolyte

The supporting electrolyte is used to increase the conductivity of the solution. The cell voltage is reduced as a result of increasing electrolyte concentration leading to decreasing in power consumption. Many textile factories use $\mathrm{NaCl}$ salt in their production process, and its presence influences the electrocoagulation. In the presence of $\mathrm{NaCl}$, anodic discharge of chlorides leads to produce $\mathrm{Cl}_{2}$, $\mathrm{HClO}$ and/or $\mathrm{OCl}^{-}$, which are strong oxidants, capable to oxidize organic compounds presented in water ${ }^{51}$.
As reported by Senthilkumar et al. ${ }^{52}, \mathrm{NaCl}$ has a better effect on the removal of Reactive Red 120.

The effect of $\mathrm{NaCl}$ concentration on $\mathrm{MB}$ was studied by applying EC technique with $20 \mathrm{~mA} / \mathrm{cm}^{2}$ current density and at natural $\mathrm{pH}$. Chloride ions reduce the contribution of other anions such as $\mathrm{HCO}_{3}{ }^{-}$and $\mathrm{SO}_{4}{ }^{2-}$ and contribute to a normal electrocoagulation ${ }^{53}$. (Fig.7) represents $\mathrm{MB}$ removal vs. $\mathrm{NaCl}$ concentration at different treatment times. It is observed that the efficiency is increased with increasing the ionic strength of the solution and reaches $100 \%$ removal in the presence of $0.1 \mathrm{M} \mathrm{NaCl}$ 
concentration. Beyond this concentration, the MB removal efficiency remains constant. A similar result was found by Salih et al. ${ }^{54}$. investigating the removal of boron from water by EC in the range of 0.01 to 0.20 $\mathrm{M} \mathrm{NaCl}$. The experimental work indicates that for concentrations higher than $0.1 \mathrm{M}$, the removal efficiency remains invariably in the same operating condition of $\mathrm{pH}=7$, current $=3 \mathrm{~mA} / \mathrm{cm}^{2}$, [Boron] = $5 \mathrm{mg} / \mathrm{L}$, gap $=0.5 \mathrm{~cm}, \mathrm{~T}=22^{\circ} \mathrm{C}$, and stirring speed $=$ $120 \mathrm{rpm}$.

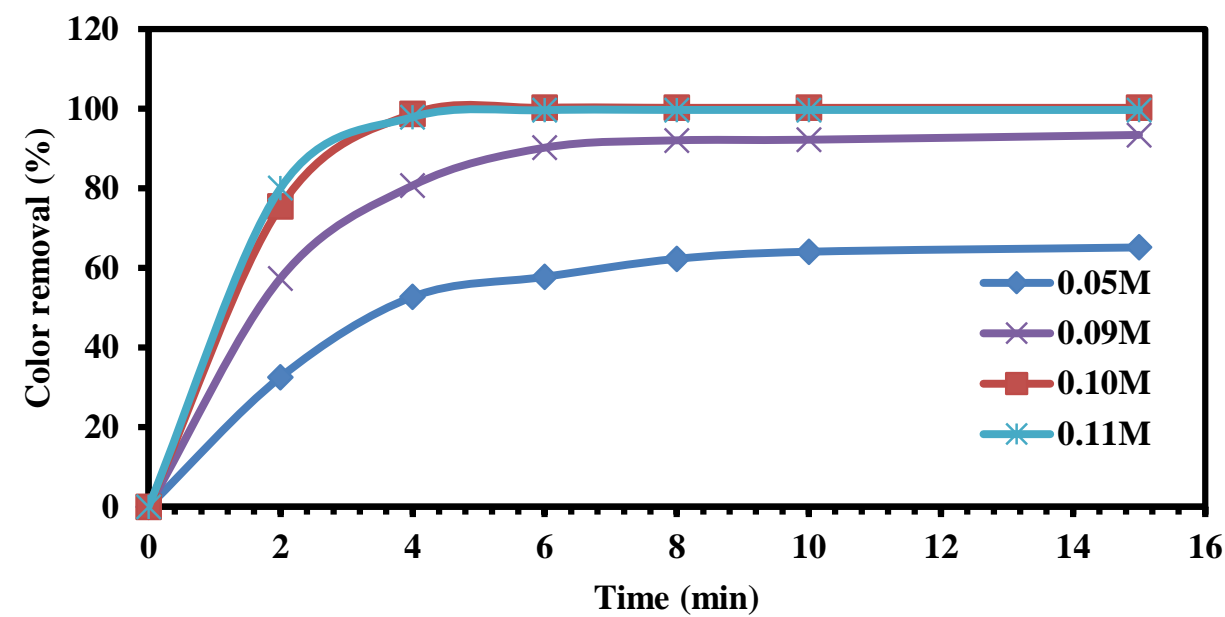

Figure 7. Effect of $\mathrm{NaCl}$ concentration on the color removal of $20 \mathrm{mg} / \mathrm{L}$ of methylene blue

\subsection{Effect of the initial pH}

The $\mathrm{pH}$ of the electrolytic solution strongly affected the efficiency of the electronic system $34,55,56$. It influences metal dissolution, nature of coagulants and metal hydroxides formation. This parameter contributes to adsorption, precipitation or destabilization and aggregation of particles ${ }^{57}$. The effect of initial $\mathrm{pH}$ for $\mathrm{MB}$ removal was carried out at the current density of $20 \mathrm{~mA} / \mathrm{cm}^{2}$ using $20 \mathrm{mg} / \mathrm{L} \mathrm{MB}$ and $0.1 \mathrm{M}$ of $\mathrm{NaCl}$, (Fig.8a). The final $\mathrm{pH}$ is increased with time and stabilized at around $\mathrm{pH}=11$ (Fig.8b); whatever its initial value. The formation of $\mathrm{OH}^{-}$at the cathode rises the solution $\mathrm{pH}$ which compensates the acidic buffer species present in the solution ${ }^{58,59}$. The stabilization of $\mathrm{pH}$ can be explained by the use of $\mathrm{NaCl}$ that produces in situ an oxidizing agent in the

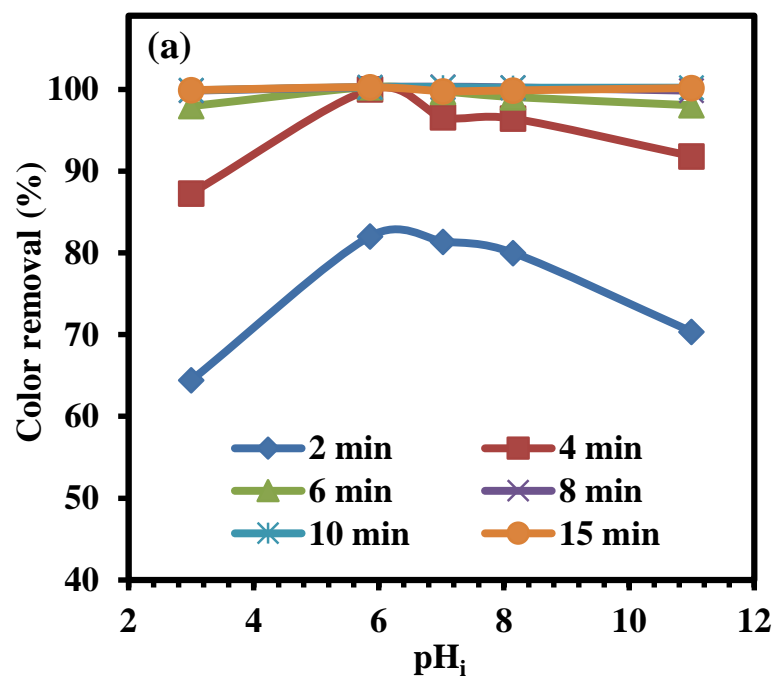

solution that keeps the $\mathrm{pH}$ below 11. In this study, it is found that the best color removal was obtained at $\mathrm{pH}$ about 5.86. As it is known, at acidic $\mathrm{pH}$ the dissolution of Iron is found to be significant than alkaline $\mathrm{pH}$ because of the decrease in corrosion rate in the presence of oxygen leading to the passivation phenomena due to layer formed ${ }^{60}$. Mollah et al. ${ }^{61}$ reported that the electrocoagulation was observed to be highly effective when the initial $\mathrm{pH}$ is slightly acidic to neutral ( $\mathrm{pH} \mathrm{3-7)}$ where metal hydroxide has a significant effect on the elimination due to its large surface area. However, beyond the near-natural $\mathrm{pH}$, less removal efficiency is observed due to the formation of $\mathrm{Fe}(\mathrm{OH})_{2}{ }^{+}, \mathrm{Fe}(\mathrm{OH})^{2+}$, and $\mathrm{Fe}(\mathrm{OH})_{4}{ }^{-}$ species ${ }^{40}$. The same results were also reported by others ${ }^{62-68}$.

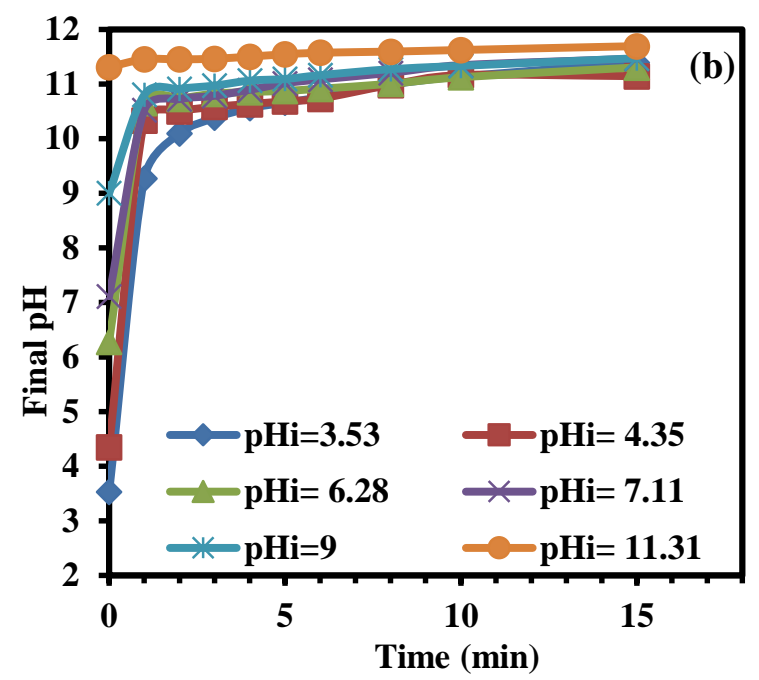

Figure 8. (a): Effect of the initial $\mathrm{pH}$; (b): Final $\mathrm{pH}$ variation during the treatment 


\subsection{Kinetic study}

In the present study, the pseudo-first-order model was employed to describe the adsorption kinetics of MB onto coagulant. The linear form of the model is presented by equation (5).

$\ln \left(\mathrm{C} / \mathrm{C}_{0}\right)=-\mathrm{K}_{\mathrm{app}} \mathrm{t}$

where, $\mathrm{C}$ and $\mathrm{C}_{0}\left(\mathrm{mgL}^{-1}\right)$ are the concentration at time $t$ and initial concentrations of $\mathrm{MB}$, respectively, $\mathrm{K}_{\mathrm{app}}$ is the pseudo-first-order apparent rate constant ( $\mathrm{min}^{-}$ $1)$.

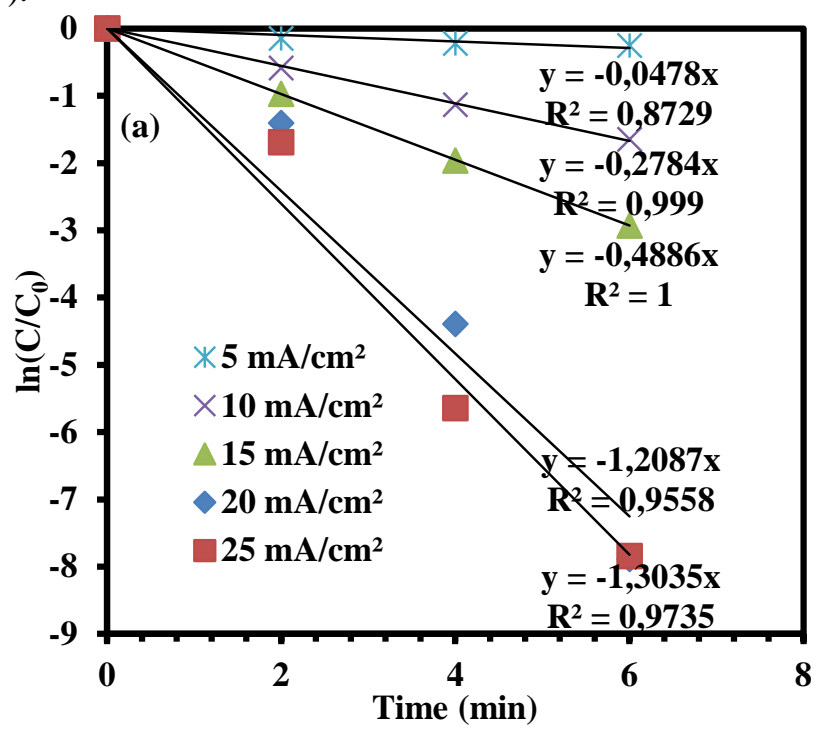

The presentation of $\ln \left(\mathrm{C} / \mathrm{C}_{0}\right)$ against $\mathrm{t}$ (Fig. 9a) at different current densities yields a straight line $\left(\mathrm{R}^{2} \approx\right.$ 1) having a slope of $K_{\text {app }}$ which increases with increasing current density as also shown in (Fig.9b), where, experimental data were extracted from section 3.5. The metal dissolution and chlorine species were increased with increasing current, which affect removal efficiency. For instance, in the case of 20 $\mathrm{mA} / \mathrm{cm}^{2}$ current density, the constant kinetic rate is around $1.21 \mathrm{~min}^{-1}$.

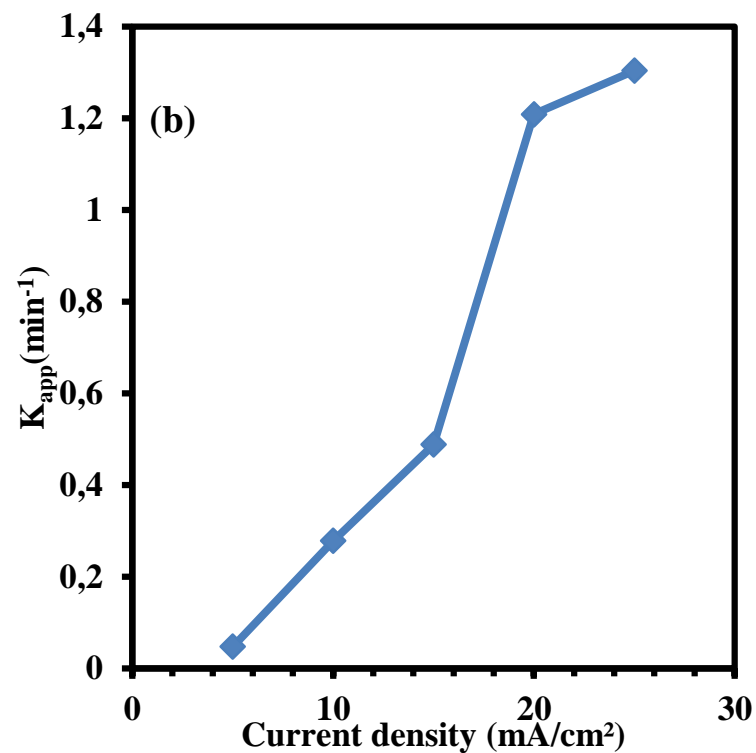

Figure 9. (a): $\ln \left(\mathrm{C} / \mathrm{C}_{0}\right)$ vs. time at different current densities; (b): Apparent rate constant vs. current density

\subsection{COD and TOC removal}

The chemical oxygen demand (COD) and total organic carbon (TOC) removal have been performed using $20 \mathrm{mg} / \mathrm{L}$ of $\mathrm{MB}$ at a current density of 20 $\mathrm{mA} / \mathrm{cm}^{2}$ using $0.1 \mathrm{M}$ of $\mathrm{NaCl}$ and at natural $\mathrm{pH}$. Results are shown in (Fig. 10a) and (Fig.10b), for COD and TOC removal, respectively. (Fig.10a)

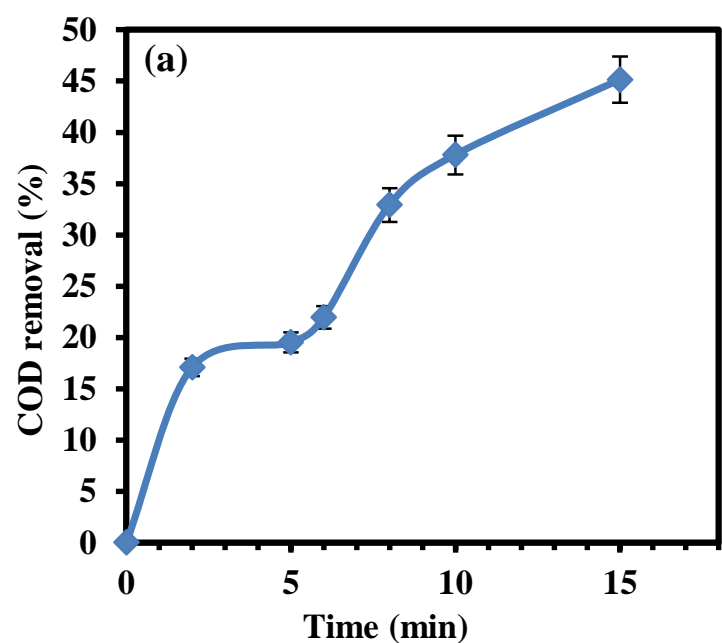

showed that after 15 minutes of treatment, about $45 \%$ COD was achieved. The low value of COD removal may be due to the presence of by-products formed by direct oxidation at the anode surface. (Fig.10b) shows that the TOC removal is increased up to $51 \%$ with increasing time up to $15 \mathrm{~min}$ then it is decreased.

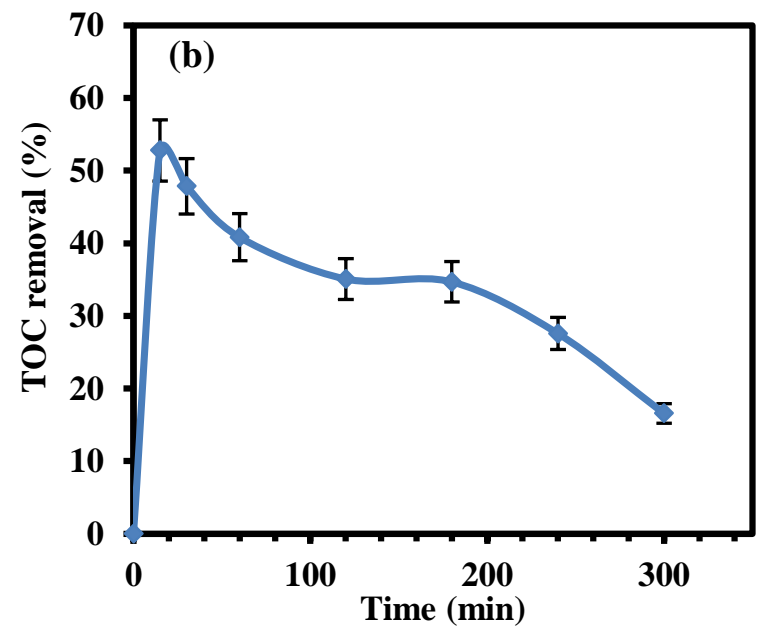

Figure 10. Variation of (a), COD, (b), TOC removals of methylene blue vs. time

The observed variation in the TOC removal may be due to the formation of sludge, which spreads MB in the solution. As the reaction time increased up to 15 min, the formation of sludge is increased, which leads to power loss and a higher dissolution of the anode. However, the decrease in TOC removal may be related to increases in cell temperature, which has an adverse effect on the adsorption of methylene blue on 
the sludge surface. Therefore, 15 minutes time is considered as the maximum time for the removal of TOC. The TOC or COD can be further reduced by combining this treatment with another technique as anodic oxidation.

\subsection{Power consumption}

The power consumption for the feasibility of electrocoagulation process was calculated using
(Eq.4) for $20 \mathrm{mg} / \mathrm{L} \mathrm{MB}, 0.1 \mathrm{M} \mathrm{NaCl}$ at natural $\mathrm{pH}$, and the result is represented in (Fig.11). The power consumption increases with applied current density up to $20 \mathrm{~mA} / \mathrm{cm}^{2}$ and remains almost constant beyond this value. The obtained value at $20 \mathrm{~mA} / \mathrm{cm}^{2}$ was around $5.84 \mathrm{KWh} / \mathrm{m}^{3}$ over 15 minutes of electrolysis. As reported by Yuksel et al. ${ }^{15}$ stainless steel has the lowest power consumption in comparison with Iron electrodes.

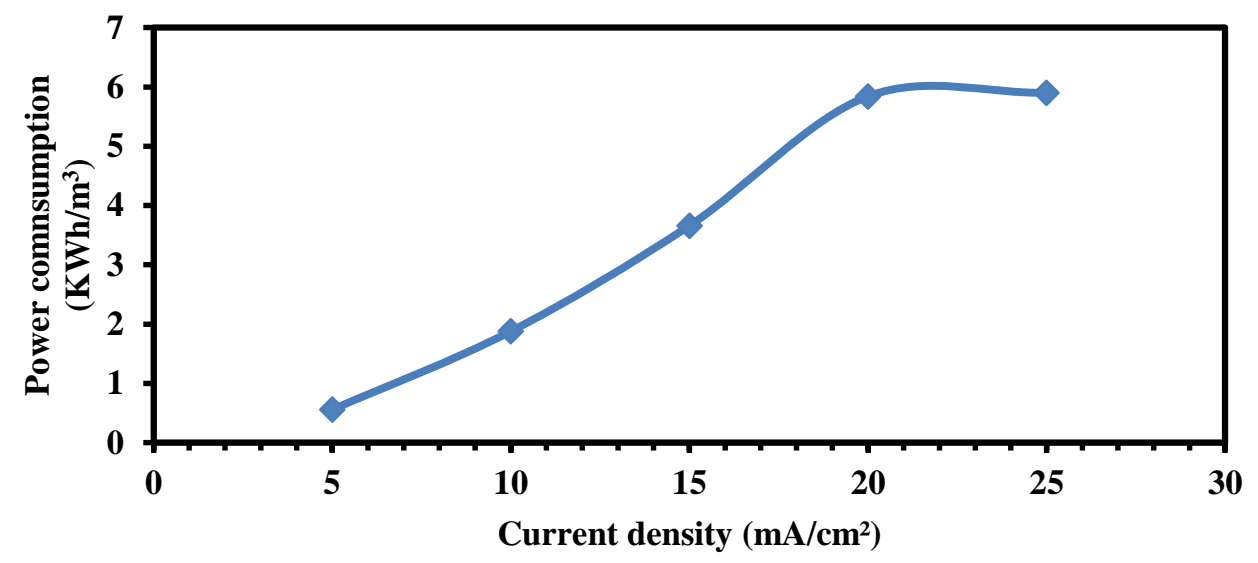

Figure 11. Power consumption $\left(\mathrm{KWh} / \mathrm{m}^{3}\right)$ vs. Current density $\left(\mathrm{mA} / \mathrm{cm}^{2}\right)$

\subsection{Sludge formation}

According to Faraday's law, the higher current density increases both the dissolution of anode and sludge production. (Fig.12) shows the quantity of sludge formed at different current density over15 minutes of electrolysis using $20 \mathrm{mg} / \mathrm{L} \mathrm{MB}, 0.1 \mathrm{M} \mathrm{NaCl}$ and at natural $\mathrm{pH}$. Similar results were also observed by other workers ${ }^{69}$.

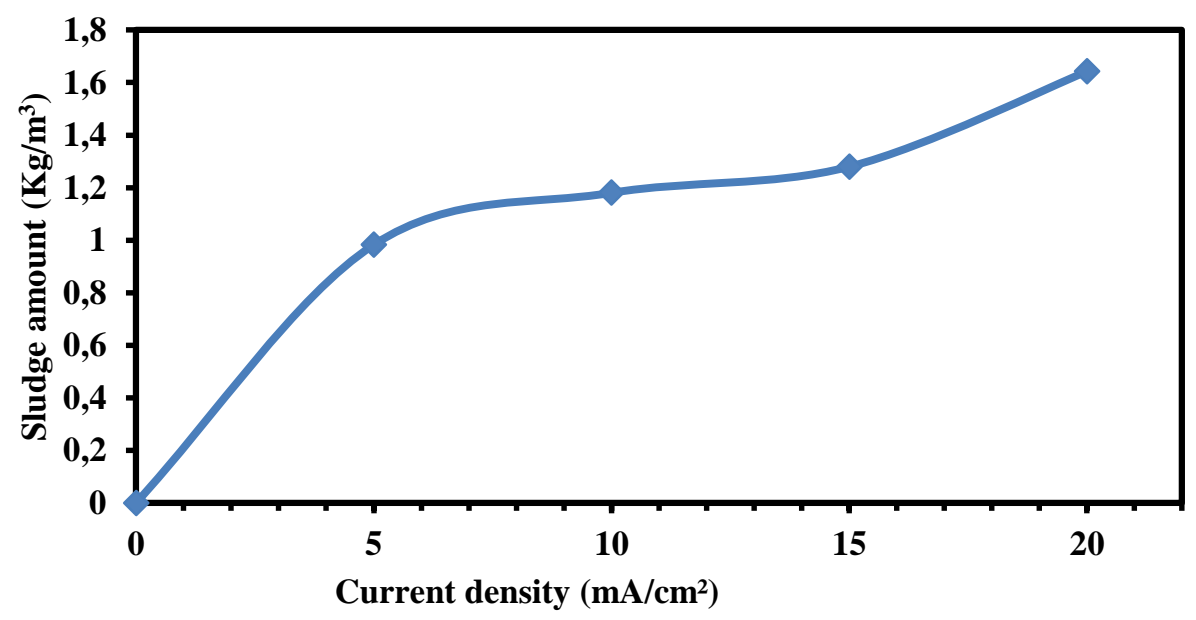

Figure 12. Sludge quantity vs. Current density at 15 min of reaction time

\subsection{SEM and EDS analysis}

The formed sludge using $20 \mathrm{mg} / \mathrm{L} \mathrm{MB}, 0.1 \mathrm{M} \mathrm{NaCl}$, at natural $\mathrm{pH}$ and $20 \mathrm{~mA} / \mathrm{cm}^{2}$ was characterized using SEM and EDS analysis. After being dehydrated at $105^{\circ} \mathrm{C}$, it was annealed at $300^{\circ} \mathrm{C}$ for $1 \mathrm{~h}$. Figures 13 a and $b$ present SEM micrographs of the sludge showing a non-homogenized surface with different sized particles. Fig. 13c presents EDS analysis which affirms the presence of different metallic elements such as $\mathrm{Cr}$ and $\mathrm{Ni}$. The presence of those heavy metals reflects the power of this process to transfer the pollution from water to the formed sludge. One can see that the solid contains regarding the atomic ratio of about $50 \%$ oxygen (oxide) and more $\mathrm{Cr}$ percentage comparable to that of Fe. As reported by Kim et al. ${ }^{70}$ the EC process has great efficiency in removing heavy metals $(\mathrm{Cu}, \mathrm{Ni}, \mathrm{Zn}$, and $\mathrm{Cr}$ ) from wastewater during electrocoagulation using $\mathrm{Fe}$ and $\mathrm{Al}$ electrodes. Further characterizations of treated solutions and the formed sludge are currently ongoing in our lab to carry out the best conditions for final disposal. 

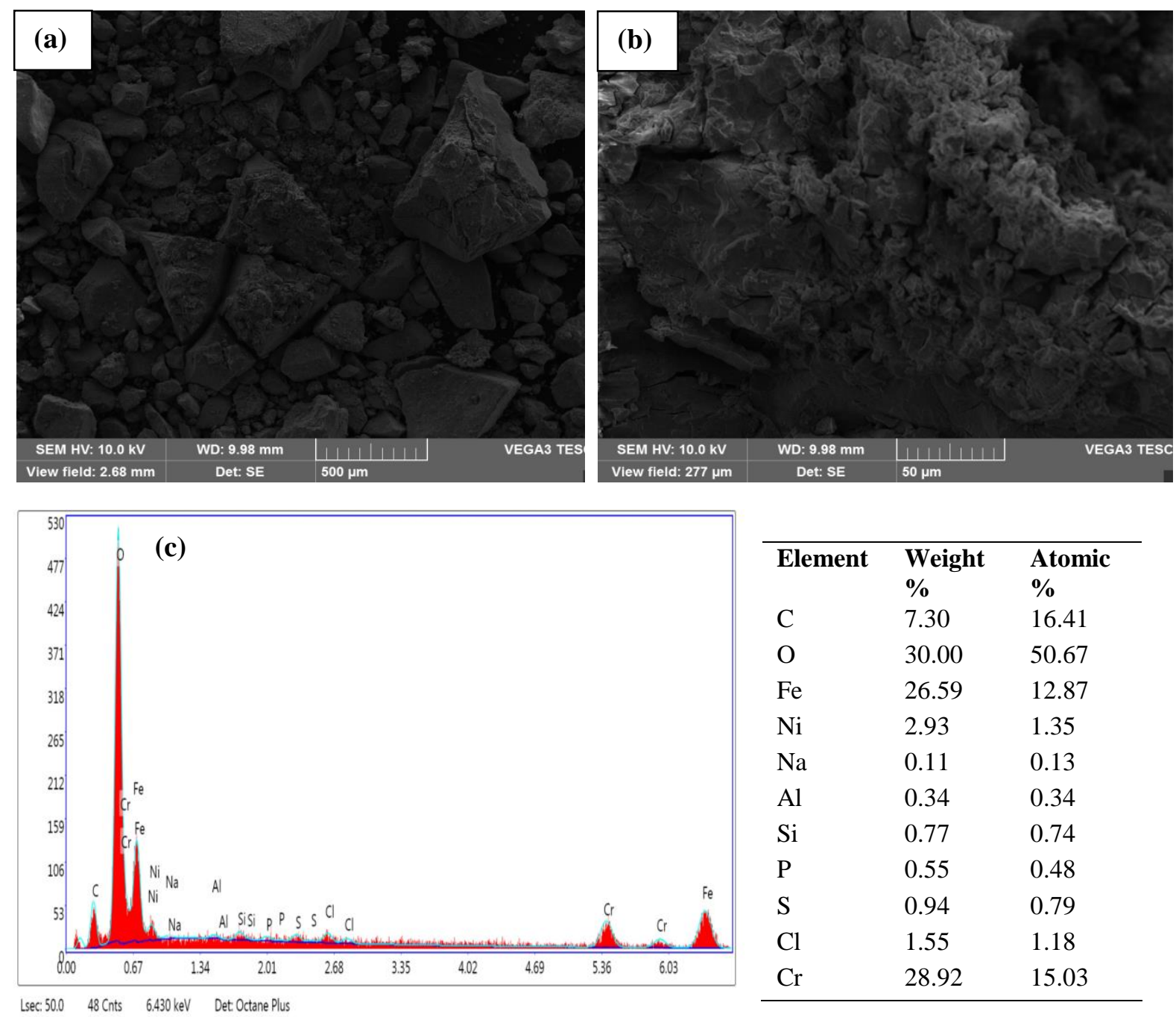

\begin{tabular}{lll}
\hline Element & $\begin{array}{l}\text { Weight } \\
\mathbf{\%}\end{array}$ & $\begin{array}{l}\text { Atomic } \\
\text { \% }\end{array}$ \\
$\mathrm{C}$ & 7.30 & 16.41 \\
$\mathrm{O}$ & 30.00 & 50.67 \\
$\mathrm{Fe}$ & 26.59 & 12.87 \\
$\mathrm{Ni}$ & 2.93 & 1.35 \\
$\mathrm{Na}$ & 0.11 & 0.13 \\
$\mathrm{Al}$ & 0.34 & 0.34 \\
$\mathrm{Si}$ & 0.77 & 0.74 \\
$\mathrm{P}$ & 0.55 & 0.48 \\
$\mathrm{~S}$ & 0.94 & 0.79 \\
$\mathrm{Cl}$ & 1.55 & 1.18 \\
$\mathrm{Cr}$ & 28.92 & 15.03 \\
\hline
\end{tabular}

Figure 13. (a) and (b): SEM micrographs, (c): Energy-dispersive X-ray spectroscopy (EDS) spectrum of sludge

\section{Conclusion}

The removal of MB dye from aqueous solutions was performed in a batch-stirred reactor using EC process. The effect of some operating conditions like the nature of the electrodes, inter-electrode spacing, power consumption, the initial dye concentration, steering speed, the current density, initial $\mathrm{pH}$, reaction time, the dye concentration, $\mathrm{NaCl}$ concentration, and parameters were tested and optimized. MB elimination at stainless steel electrodes was found to be better compared to Iron electrodes. The objective is to carry out the best way to remove MB from aqueous solution with low power consumption. The optimal conditions for $20 \mathrm{mg} / \mathrm{L} \mathrm{MB}$ treatment were: $20 \mathrm{~mA} / \mathrm{cm}^{2}$ current density using stainless steel electrodes with an inter-distance of $1.5 \mathrm{~cm}$ and 850 $\mathrm{rpm}$ for the batch-stirred reactor in the presence of 0.1 $\mathrm{M}$ of $\mathrm{NaCl}$, at natural $\mathrm{pH} .100 \%$ of decolorization was achieved within 6 minutes of electrolysis time.

Furthermore, $41 \%$ of COD and $51 \%$ of TOC were removed after 15 minutes of treatment. To increase the COD and TOC removals, combined treatment is needed. According to these parameters, the power consumption at $15 \mathrm{~min}$ of electrolysis time was around $5.84 \mathrm{KWh} / \mathrm{m}^{3}$. The MB removal follows the pseudo-first-order kinetic model with a constant kinetic rate of about $1.21 \mathrm{~min}^{-1}$ using $20 \mathrm{~mA} / \mathrm{cm}^{2}$. As a result of dye removal, a small amount of sludge around $1.6 \mathrm{Kg} / \mathrm{m}^{3}$ is generated in the optimal experimental conditions. The sludge characterization shows the presence of different metallic elements such as $\mathrm{Cr}$ and $\mathrm{Ni}$, reflecting the power of this process to transfer the pollution from water to the formed sludge. The work is in progress to characterize the effluent and the sludge for better reuse.

\section{Acknowledgements}

The authors would like to thank the University of Ibn Zohr, Agadir for making all the necessary resources available for this work. FET thanks CNRST for providing the fellowship. This work is done in the framework of the European ERANET MED Water13_043 project SETPROpER: (Sustainable treatment processes of effluents for reuse of water in agriculture) with the financial support of MOROCCAN MESRSFC. 


\section{Conflict of interest}

On behalf of all authors, the corresponding author states that there is no conflict of interest.

\section{References}

1- M. Sala, M.C. Gutiérrez-Bouzán, Electrochemical Techniques in Textile Processes and Wastewater Treatment, International Journal of Photoenergy, 2012. https://doi.org/10.1155/2012/629103.

2- A. Sakalis, K. Fytianos, U. Nickel, A. Voulgaropoulos, A comparative study of platinised titanium and Niobe/synthetic diamond as anodes in the electrochemical treatment of textile wastewater, Chem. Eng. J., 2006, 119, 127-133.

3- M. Alizadeh, E. Ghahramani, M. Zarrabi and S. Hashemi, Efficient De-colorization of Methylene Blue by Electrocoagulation Method: Comparison of Iron and Aluminum Electrode, Iran. J. Chem. Chem. Eng., 2015, 34, 39-47.

4- D.G. Bassyouni, H.A. Hamad, E.-S.Z. El-Ashtoukhy, N.K. Amin, M.M.A. El-Latif, Comparative performance of anodic oxidation and electrocoagulation as clean processes for electrocatalytic degradation of diazo dye Acid Brown 14 in aqueous medium, J. Hazard. Mater., 2017, 335, 178-187.

5- A. Mhemdi, M.A. Oturan, N. Oturan, R. Abdelhédi, S. Ammar, Electrochemical advanced oxidation of 2-chlorobenzoic acid using BDD or Pt anode and carbon felt cathode, $J$. Electroanal. Chem., 2013, 709, 111-117.

6- M. Khayet, A.Y. Zahrim, N. Hilal, Modelling and optimization of coagulation of highly concentrated industrial grade leather dye by response surface methodology, Chem. Eng. J., 2011, 167, 77-83.

7- Y.M. Slokar, A. Majcen Le Marechal, Methods of decoloration of textile wastewaters, Dyes Pigments, 1998, 37, 335-356.

8- N.S. Trivedi, S.A. Mandavgane, Fundamentals of 2, 4 Dichlorophenoxyacetic Acid Removal from Aqueous Solutions, Sep. Purif. Rev., 2018, 47, 337-354.

9- B. Kamarehie, A. Jafari, M. Ghaderpoori, M. A. Karami, K. Mousavi, A. Ghaderpoury, Catalytic ozonation process using $\mathrm{PAC} / \gamma-\mathrm{Fe}_{2} \mathrm{O}_{3}$ to Alizarin Red $\mathrm{S}$ degradation from aqueous solutions: a batch study, Chem. Eng. Commun., 2019, 206, 898-908.

10-A.Y. Zahrim, N. Hilal, Treatment of highly concentrated dye solution by coagulation/flocculation-sand filtration and nanofiltration, Water Resour. Ind., 2013, 3, 23-34.

11-H. Akrout, S. Jellali, L. Bousselmi, Enhancement of methylene blue removal by anodic oxidation using BDD electrode combined with adsorption onto sawdust, Comptes Rendus Chim., 2015, 18, 110-120.
12-C. Thakur, V.C. Srivastava, I.D. Mall, Electrochemical treatment of distillery wastewater: Parametric and residue disposal study, Chem. Eng. J., 2009, 148, 496-505.

13-M.S. Secula, I. Creţescu, S. Petrescu, An experimental study of indigo carmine removal from aqueous solution by electrocoagulation, Desalination, 2011, 277, 227-235.

14-N. Liu, Y. Wu, Removal of methylene blue by electrocoagulation: a study of the effect of operational parameters and mechanism, Ionics, 2019, 25, 3953-3960.

15-E. Yuksel, M. Eyvaz, E. Gurbulak, Electrochemical treatment of colour index reactive orange 84 and textile wastewater by using stainless steel and iron electrodes, Environ. Prog. Sustain. Energy, 2013, 32, 60-68.

16-T.-H. Kim, C. Park, E.-B. Shin, S. Kim, Decolorization of disperse and reactive dyes by continuous electrocoagulation process, Desalination, 2002, 150, 165-175.

17-D. Ghernaout, Advanced oxidation phenomena in electrocoagulation process: a myth or a reality?, Desalination Water Treat., 2013, 51, 7536-7554.

18-Z. Ye, J.R. Steter, F. Centellas, P.L. Cabot, E. Brillas, I. Sirés, Photoelectron-Fenton as posttreatment for electrocoagulated benzophenone-3loaded synthetic and urban wastewater, J. Clean. Prod., 2019, 208, 1393-1402.

19-U.D. Patel, J.P. Ruparelia, M.U. Patel, Electrocoagulation treatment of simulated floorwash containing Reactive Black 5 using iron sacrificial anode, J. Hazard. Mater., 2011, 197, 128-136.

20- A. Dalvand, M. Gholami, A. Joneidi, N.M. Mahmoodi, Dye Removal, Energy Consumption and Operating Cost of Electrocoagulation of Textile Wastewater as a Clean Process, CLEANSoil Air Water, 2011, 39, 665-672.

21-A.K. Golder, N. Hridaya, A.N. Samanta, S. Ray, Electrocoagulation of methylene blue and eosin yellowish using mild steel electrodes, J. Hazard. Mater., 2005, 127, 134-140.

22-B.M. Krishna, U.N. Murthy, B. Manoj Kumar, K.S. Lokesh, Electrochemical pretreatment of distillery wastewater using aluminum electrode, J. Appl. Electrochem., 2010, 40, 663-673.

23-F. Kirzhner, Y. Zimmels, Y. Shraiber, Combined treatment of highly contaminated winery wastewater, Sep. Purif. Technol., 2008, 63, 38-44.

24-J. Feng, Y. Sun, Z. Zheng, J. Zhang, S. Li, Y. Tian, Treatment of tannery wastewater by electrocoagulation, J. Environ. Sci., 2007, 19, 1409-1415.

25-C.-L. Lai, K.-S. Lin, Sludge conditioning characteristics of copper chemical mechanical polishing wastewaters treated by electrocoagulation, J. Hazard. Mater., 2006, 136, 183-187. 
26-H. Zazou, H. Afanga, S. Akhouairi, H. Ouchtak, A.A. Addi, R.A. Akbour, A. Assabbane, J. Douch, A. Elmchaouri, J. Duplay, A. Jada, M. Hamdani, Treatment of textile industry wastewater by electrocoagulation coupled with electrochemical advanced oxidation process, $J$. Water Process Eng., 2019, 28, 214-221.

27-D.R. Arsand, K. Kümmerer, A. F. Martins, Removal of dexamethasone from aqueous solution and hospital wastewater by electrocoagulation, Sci. Total Environ., 2013, 443, 351-357.

28-A.R. Yazdanbakhsh, M.R. Massoudinegad, S. Eliasi, A.S. Mohammadi, The influence of operational parameters on reduce of azithromyin COD from wastewater using the peroxi electrocoagulation process, J. Water Process Eng., 2015, 6, 51-57.

29-A.K. Golder, A.N. Samanta, S. Ray, Removal of $\mathrm{Cr}^{3+}$ by electrocoagulation with multiple electrodes: Bipolar and monopolar configurations, J. Hazard. Mater., 2007, 141, 653-661.

30-F. Akbal, S. Camc1, Copper, chromium and nickel removal from metal plating wastewater by electro coagulation, Desalination, 2011, 269, 214-222.

31-A.H. Mahvi, S.J.A. Ebrahimi, A. Mesdaghinia, H. Gharibi, M.H. Sowlat, Performance evaluation of a continuous bipolar electrocoagulation/electrooxidationelectroflotation (ECEO-EF) reactor designed for simultaneous removal of ammonia and phosphate from wastewater effluent, J. Hazard. Mater., 2011, 192, 1267-1274.

32-M. Murugananthan, G.B. Raju, S. Prabhakar, Removal of sulfide, sulfate and sulfite ions by electrocoagulation, J. Hazard. Mater., 2004, 109, 37-44.

33-M. Rafatullah, O. Sulaiman, R. Hashim, A. Ahmad, Adsorption of methylene blue on lowcost adsorbents: A review, J. Hazard. Mater., 2010, 177, 70-80.

34-K.S. Hashim, A.H. Hussein, S.L. Zubaidi, P. Kot, L. Kraidi, R. Alkhaddar, A. Shaw, R. Alwash, Effect of initial $\mathrm{pH}$ value on the removal of reactive black dye from water by electrocoagulation (EC) method, J. Phys. Conf. Ser., 2019, 1294, 072017.

35-M.M. Emamjomeh, M. Mousazadeh, N. Mokhtari, H.A. Jamali, M. Makkiabadi, Z. Naghdali, K.S. Hashim, R. Ghanbari, Simultaneous removal of phenol and linear alkylbenzene sulfonate from automotive service station wastewater: Optimization of coupled electrochemical and physical processes, Sep. Sci. Technol., 2019, 1-11.

36-K.S. Hashim, N.H. Al-Saati, S.S. Alquzweeni, S.L. Zubaidi, P. Kot, L. Kraidi, A.H. Hussein, R. Alkhaddar, A. Shaw, R. Alwash, Decolourization of dye solutions by electrocoagulation: an investigation of the effect of operational parameters, IOP Conf. Ser. Mater. Sci. Eng., 2019, 584, 012024.

37-K.S. Hashim, R. AlKhaddar, A. Shaw, P. Kot, D. Al-Jumeily, R. Alwash, M.H. Aljefery, in Advances in Water Resources Engineering and Management, 2020, 39, 219-235.

38-K.S. Hashim, I. Adeola Idowu, N. Jasim, R. Al Khaddar, A. Shaw, D. Phipps, P. Kot, M. Ortoneda Pedrola, A.W. Alattabi, M. Abdulredha, R. Alwash, K.H. Teng, K.H. Joshi, M. Hashim Aljefery, Removal of phosphate from River water using a new baffle plates electrochemical reactor, MethodsX, 2018, 5, 1413-1418.

39-C.-T. Wang, W.-L. Chou, Y.-M. Kuo, Removal of COD from laundry wastewater by electrocoagulation / electroflotation, J. Hazard. Mater., 2009, 164, 81-86.

40-K. Gautam, S. Kumar, S. Kamsonlian, Decolourization of Reactive Dye from Aqueous Solution using Electrocoagulation: Kinetics and Isothermal Study, Z. Für Phys. Chem., 2019, 233, 1447-1468.

41-K.S. Hashim, A. Shaw, R. Al Khaddar, M.O. Pedrola, D. Phipps, Iron removal, energy consumption and operating cost of electrocoagulation of drinking water using a new flow column reactor, J. Environ. Manage., 2017, 189, 98-108.

42-S. Aoudj, A. Khelifa, N. Drouiche, M. Hecini, H. Hamitouche, Electrocoagulation process applied to wasteswater containing dyes from textile industry, Chem. Eng. Process. Process Intensif., 2010, 49, 1176-1182.

43-N. Modirshahla, M.A. Behnajady, S. Kooshaiian, Investigation of the effect of different electrode connections on the removal efficiency of Tartrazine from aqueous solutions by electrocoagulation, Dyes Pigments, 2007, 74, 249-257.

44-M.S. Mahmoud, J.Y. Farah, T.E. Farrag, Enhanced removal of Methylene Blue by electrocoagulation using iron electrodes, Egypt. J. Pet., 2013, 22, 211-216.

45-K.S. Hashim, A. Shaw, R. Al Khaddar, M.O. Pedrola, D. Phipps, Energy-efficient electrocoagulation using a new flow column reactor to remove nitrate from drinking water Experimental, statistical, and economic approach, J. Environ. Manage., 2017, 196, 224-233.

46-V. Khandegar, A.K. Saroha, Electrocoagulation for the treatment of textile industry effluent A review, J. Environ. Manage., 2013, 128, 949-963.

47-G.R. Mohammed, T.M. Zewail, Y.A. El-Tawail, Investigation of color removal from methylene blue containing solutions by electrocoagulation/flotation in a batch-agitated electrochemical reactor, Environ. Prog. Sustain. Energy, 2014, 33, 369-377. 
48-K.S. Hashim, A. Shaw, R. Al Khaddar, M. Ortoneda Pedrola, D. Phipps, Defluoridation of drinking water using a new flow columnelectrocoagulation reactor (FCER)-Experimental, statistical, and economic approach, J. Environ. Manage., 2017, 197, 80-88.

49-B.A. Abdulhadi, P. Kot, K.S. Hashim, A. Shaw, R.A. Khaddar, Influence of current density and electrodes spacing on reactive red 120 dye removal from dyed water using electrocoagulation/electroflotation (EC/EF) process, IOP Conf. Ser. Mater. Sci. Eng., 2019, 584, 012035.

50-N. Adhoum, L. Monser, N. Bellakhal, J.-E. Belgaied, Treatment of electroplating wastewater containing $\mathrm{Cu}^{2+}, \mathrm{Zn}^{2+}$ and $\mathrm{Cr}(\mathrm{VI})$ by electrocoagulation, J. Hazard. Mater., 2004, 112, 207-213.

51-Z. Isik, E.B. Arikan, Y. Ozay, H.D. Bouras, N. Dizge, Electrocoagulation and electrooxidation pre-treatment effect on fungal treatment of pistachio processing wastewater, Chemosphere, 2020, 244, 125383.

52-P. Senthil Kumar, N. Umaiyambika, R. Gayathri, Dye removal from aqueous solution by electrocoagulation process using stainless steel electrodes, Environ. Eng. Manag. J., 2010, 9, 1031-1037.

53-C. Guohua, C. Xueming, Y. Po Lock, Electrocoagulation and Electroflotation of Restaurant Wastewater, J. Environ. Eng., 2000, 126, 858-863.

54-W.M. Salih, S.K. Alnasri, A.A.A. Abdalaali, Removal of Boron from Simulated Iraqi Surface Water by Electrocoagulation Method, J. Eng., 2012, 18, 1266-1284.

55-M. Khemis, J.-P. Leclerc, G. Tanguy, G. Valentin, F. Lapicque, Treatment of industrial liquid wastes by electrocoagulation:

Experimental investigations and an overall interpretation model, Chem. Eng. Sci., 2006, 61, 3602-3609.

56-K.S. Hashim, R. Al Khaddar, N. Jasim, A. Shaw, D. Phipps, P. Kot, M.O. Pedrola, A.W. Alattabi, M. Abdulredha, R. Alawsh, Electrocoagulation as a green technology for phosphate removal from river water, Sep. Purif. Technol., 2019, 210, 135-144.

57-A.S. Fajardo, R.C. Martins, D.R. Silva, C.A. Martínez-Huitle, R.M. Quinta-Ferreira, Dye wastewaters treatment using batch and recirculation flow electrocoagulation systems, $J$. Electroanal. Chem., 2017, 801, 30-37.

58-M. Kobya, F. Ulu, U. Gebologlu, E. Demirbas, M.S. Oncel, Treatment of potable water containing a low concentration of arsenic with electrocoagulation: Different connection modes and $\mathrm{Fe}-\mathrm{Al}$ electrodes, Sep. Purif. Technol., 2011, 77, 283-293.

59-M.Y.A. Mollah, S.R. Pathak, P.K. Patil,
M. Vayuvegula, T.S. Agrawal, J.A.G. Gomes, M. Kesmez, D.L. Cocke, Treatment of orange II azo-dye by electrocoagulation (EC) technique in a continuous flow cell using sacrificial iron electrodes, J. Hazard. Mater., 2004, 109, 165-171.

60-O. Sahu, B. Mazumdar, P.K. Chaudhari, Treatment of wastewater by electrocoagulation: a review, Environ. Sci. Pollut. Res., 2014, 21, 2397-2413.

61-M.Y.A. Mollah, P. Morkovsky, J.A.G. Gomes, M. Kesmez, J. Parga, D.L. Cocke, Fundamentals, present and future perspectives of electrocoagulation, J. Hazard. Mater., 2004, 114, 199-210.

62-İ. Arslan-Alaton, I. Kabdaşl1, B. Vardar, O. Tünay, Electrocoagulation of simulated reactive dyebath effluent with aluminum and stainless steel electrodes, J. Hazard. Mater., 2009, 164, 1586-1594.

63- K.A. Selim, F.I.E. Hosiny, M.A. A. Khalek, I. Osama, Kinetics and Thermodynamics of Some Heavy Metals Removal from Industrial Effluents Through Electro-Flotation Process, Colloid Surf. Sci., 2017, 2, 47-53.

64-M. Abdel Khalek, F. El-Hosiny, K. Selim, I. Osama, Produced Water Treatment Using a New Designed Electroflotation Cell, Int. J. Res. Ind. Eng., 2017, 6, 823-883.

65-F. El-Hosiny, M. Abdeldayem AbdelKhalek, K. Selim, I. Osama, A Designed Electro-flotation Cell for Dye Removal from Wastewater, J. Appl. Res. Ind. Eng., 2017, 4, 133-147.

66-R. Amin, F.I. El-Hosiny, M.A. AbdelKhalek, S.S. Ibrahim, A. Yehia, Statistical Design of Column Flotation Parameters for Beneficiation of Egyptian Oil Shale, Int. J. Res. Ind. Eng., 2017, 4, 133-147.

67-F.I. El-Hosiny, M.A. Abdel-Khalek, K.A. Selim, I. Osama, Physicochemical study of dye removal using electro-coagulation-flotation process, Physicochem. Probl. Miner. Process., 2018, 54, 321-333.

68-M.A. Abdel Khalek, F.I. El Hosiny, K.A. Selim, I. Osama, A novel continuous electroflotation cell design for industrial effluent treatment, Sustain. Water Resour. Manag., 2019, 5, 457-466.

69-J.A.G. Gomes, P. Daida, M. Kesmez, M. Weir, H. Moreno, J.R. Parga, G. Irwin, H. McWhinney, T. Grady, E. Peterson, D.L. Cocke, Arsenic removal by electrocoagulation using combined Al-Fe electrode system and characterization of products, J. Hazard. Mater., 2007, 139, 220-231.

70-T. Kim, T.-K. Kim, K.-D. Zoh, Removal mechanism of heavy metal $(\mathrm{Cu}, \mathrm{Ni}, \mathrm{Zn}$, and $\mathrm{Cr})$ in the presence of cyanide during electrocoagulation using $\mathrm{Fe}$ and $\mathrm{Al}$ electrodes, $J$. Water Process Eng., 2020, 33, 101109. 